\title{
Kernos
}

Revue internationale et pluridisciplinaire de religion grecque antique

$23 \mid 2010$

Varia

\section{Revue des actes de colloques, ouvrages collectifs et anthologies}

\section{OpenEdition}

Journals

Édition électronique

URL : http://journals.openedition.org/kernos/1670

DOI : 10.4000/kernos. 1670

ISSN : 2034-7871

Éditeur

Centre international d'étude de la religion grecque antique

Édition imprimée

Date de publication : 1 janvier 2010

Pagination : 412-417

ISSN : 0776-3824

\section{Référence électronique}

"Revue des actes de colloques, ouvrages collectifs et anthologies », Kernos [En ligne], 23 | 2010, mis en ligne le 15 septembre 2011, consulté le 30 avril 2019. URL : http://journals.openedition.org/ kernos/1670

Ce document a été généré automatiquement le 30 avril 2019.

Kernos 


\section{Revue des actes de colloques, ouvrages collectifs et anthologies}

\section{Actes de colloques, ouvrages collectifs et anthologies}

1 Claudia ANTONETTI, Stefania DE VIDo (éds), Temi Selinunti, Pisa, Edizioni ETS, 2009.

C. Antonetti, Riflessioni su Zeus Agoraios a Selinunte, p. 29-51; S.M. Bertesago, Figurine fittili da Bitalemi (Gela) e dalla Malophoros (Selinunte): appunti per uno studio comparato di alcune classi della coroplastica votiva, p. 53-69; S. Crippa, M. De Simon, Sulla valenza pubblica dei rituali defissori a Selinunte, p. 93-104; C. Marconi, Il rilievo con il ratto di Persephone dal

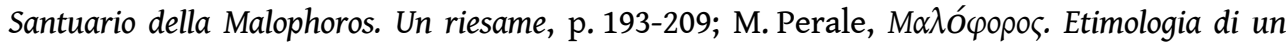
teonimo, p. 229-244.

2 Jean-Pierre AYGON, Corinne BONNET, Christina NOACCO (dir.), La Mythologie de l'Antiquité à la Modernité. Appropriation - Adaptation - Détournement, Rennes, Presses Universitaires de Rennes, 2009 (Collection « Interférences »).

Claude Calame, L'enlèvement de la belle Hélène et la tradition politique de la poétique grecque: réinterprétations et controverses, p. 17-33; Emmanuelle Jouët-Pastré, Le mythe platonicien lieu de l'imagination rationnelle, p. 35-44; Gabriella Pironti, «Ce mythos n'est pas de moi, je le tiens de ma mère. » Cosmogonies grecques et savoir partagé, p. 45-57; Jocelyne Peigney, La mythologie d'Aristophane : les monstres de la comédie, parodie et création, p. 61-71.

Lydie BoDIou, Véronique MEHL (éds), La religion des femmes en Grèce ancienne. Mythes, cultes et société, Rennes, Presses universitaires de Rennes, 2009 (Collection « Histoire»). ISBN : 978-2-7535-0882-8.

Violaine Sebillote-Cuchet, La fabrique d'une hérö̈ne au Ve siècle: Hérodote et Artémise d'Halicarnasse, p. 19-32; Sandra Boehringer, Monter au ciel: le baiser de Kallistô et d'Artémis dans la mythologie grecque, p. 33-50; Philippe Monbrun, Nausikaa, Artémis et le palmier de Délos: les «belles plantes» du chant VI de l'Odyssée, p. 51-64; Pierre Brulé, Artémis en rade de Cork ou "Quand je tambourinais sur la route de Brauron... ", p. 65-82; Claude Calame, Iphigénie à Brauron: étiologie poétique et paysage artémisien, p. 83-92; Vinciane Pirenne-Delforge Gabriella Pironti, La féminité des déesses à l'épreuve des épiclèses: le cas d'Héra, p. 95-109; 
Jacques Oulhen, Les noms théophores composés féminins à Athènes, p. 111-143; Pauline Schmitt Pantel, La religion et l'arété des femmes. À propos des Vertus de femmes de Plutarque, p. 145-159; Claudine Leduc, Poésie et politique dans le mythe de l'autochtonie athénienne, p. 161-170; Lydie Bodiou - Véronique Mehl, Des intimités olfactives, des affinités électives: femmes, rites et parfums, p. 173-174; Lydie Bodiou, Quand vient l'âge fleuri des jeunes filles, p. 175-191; Véronique Mehl, Le temps venu de la maternité, p. 193-206; Florence Gherchanoc, Des cadeaux pour numphai : dôra, anakaluptêria et epaulia, p. 207-223; Jérôme Wilgaux, De l'exil au partage: la transmission féminine des appartenances parentales et religieuses, p. 225-237.

4 Lydie BoDIOU, Véronique MEHL, Jacques oUlHEN, Francis PRost, Jérôme WILGAUX (dir.), Chemin faisant. Mythes, cultes et société en Grèce ancienne. Mélanges en l'honneur de Pierre Brulé, Rennes, Presses universitaires de Rennes, 2009. 1 vol. 15,5 × 24 cm, 314 p. (Collection « Histoire »). ISBN : 978-2-7535-0946-7.

Louise Bruit-Zaidman, Les femmes et le religieux dans les Lois de Platon, p. 115-124; Karine Karila-Cohen, Les filles d'Athènes à Delphes: femmes, religion et société à travers l'exemple des canéphores de la Pythaïde, p. 133-142; Claudine Leduc, L'énigmatique Kourotrophos et l'olivier de l'Acropole, p. 143-163; Robert Parker, $\tau i ́ \varsigma$ ó $\theta u ́ \omega v$, p. 167-171; Madeleine Jost, À propos des généalogies de Pan, p. 173-180; Paolo Scarpi, Les visages du héros, discours mythique et schéma rituel, pour une projection panhellénique, p. 181-191; Sylvain Lebreton, Dionysos Ômèstès (Plutarque, Thémistocle, 13; Antoine, 24), p. 193-203; Corinne Bonnet, Le visage et le nom. Réflexions sur les interfaces divines à la lumière de la documentation proche-orientale, p. 205-214; Stella Georgoudi, Questions pythiques: retour sur le(s) trépied(s) et le laurier d'Apollon, p. 215-232; Rachel Touzé, Le myrte et Aphrodite, quelque part entre le désir et le dégoût, p. 249-260; Gaucelm Boismenu, "La vierge sans mère»: les métamorphoses d'Athéna adolescente dans l'Odyssée, p. 261-270; Véronique Dasen, Une "Baubô» sur une gemme magique, p. 271-284.

5 John BODEL, Mika KAJAVA (éds), Dediche Sacre nel mondo greco-romano. Diffusione, funzioni, tipologie/Religious Dedications in the Greco-Roman World. Distribution, Typology, Use. Institutum Romanum Finlandiae, American Academy in Rome, 19-20 aprile 2006, Roma, Institutum Romanum Finlandiae, 2009 (Acta Instituti Romani Finlandiae, 35).

John Bodel, "Sacred dedications": A problem of definitions, p. 17-30; Paola Lombardi, Av $\alpha \theta \varepsilon ́ \tau \omega$

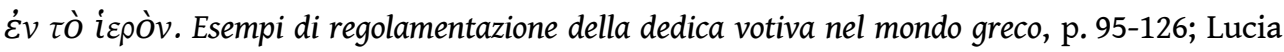
d'Amore, Dediche sacre e ginnasi: la documentazione epigrafica di età ellenistica, p. 161-180; Giulio Vallarino, I dedicanti di cos in età ellenistica: il caso dei magistrati eponimi tra polis e demi , p. 181-207; Mika Kajava, Osservazioni sulle dediche sacre nei contesti oracolari, p. 209-225; Gabriella Bevilacqua, Dediche ad Hermes, p. 227-244.

6 Corinne BONNET, Vinciane PIRENNE-DELFORGE, Danny PRAET (éds), Les religions orientales dans le monde grec et romain : cent ans après Cumont (1906-2006). Bilan historique et historiographique. Colloque de Rome, 16-18 novembre 2006, Bruxelles/Rome, Institut Historique Belge de Rome, 2009 (Institut Historique Belge de Rome. Études de philologie, d'archéologie et d'histoire anciennes, 45). ISBN : 978-90-74461-71-9.

Christoph Auffarth, Marie-Françoise Baslez, Sergio Ribichini, Appréhender les religions en contact, p. 43-62; Laurent Bricault, Francesca Prescendi, Une "théologie en images»?, p. 63-79; Attilio Mastrocinque, Culti orientali e magia: alcune riflessioni, p. 81-87; Guy G. Stroumsa, Ex oriente numen.From orientalism to oriental religions, p. 91-103; Walter Burkert, 'Orient' since Franz Cumont: Enrichment and Death of a Concept, p. 105-117; Jaime Alvar, 
Promenade por un campo de ruinas. Religiones orientales y cultos mistéricos : el poder de los conceptos y el valor de la taxonomía, p. 119-134; Paolo Xella, "Syncrétisme " comme catégorie conceptuelle: une notion utile?, p. 135-150; Ted Kaizer, Patterns of worship in Dura-Europos. A case study of religious life in the Classical Levant outside the main cult centres, p. 153-172; Richard Veymiers, Sérapis sur les gemmes et bijoux antiques. Un portrait du dieu en images, p. 187-214; Jean-Marie Pailler, Sabazios. La construction d'une figure divine dans le monde gréco-romain, p. 257-291; Yulia Ustinova, Orientalization: Once, Twice, or More? Iranian Elements in the Religion of the Greek Cities of the Northern Black Sea Littoral, p. 311-324; Elena Muñiz Grijalvo, The Cult of the Egyptian Gods in Roman Athens, p. 325-341; Pier Franco Beatrice, The Oriental Religions and Porphyry's Universal Way for the Soul's Deliverance, p. 343-368.

Michel CARTRY, Jean-Louis DURAND, Renée KOCH PIETTRE (éds), Architecturer l'invisible. Autels, ligatures, écritures, Turnhout, Brepols, 2009 (Bibliothèque de l'École des Hautes Études, Sciences religieuses, 138).

Dominique Jaillard, Espaces hermaïques du sacrifice, p. 61-79; Ioanna Patera, Les offrandes durables dans l'espace sacrificiel, p. 83-96; Edoarda Barra, Du laurier, du trépied, de l'eau et de la faille de Delphes, p. 137-151; Gabriella Pironti, Sous le ciel d'Éryx. À propos d'Élien, Sur la Nature des animaux, X, 50, p. 221-229; Marcello Carastro, Les liens de l'écriture. Katadesmoi et instances de l'enchaînement, p. 261-291; Renée Koch Piettre, Un serment gravé dans une cuve , p. 361-390; Bernard Mezzadri, Le sacrifice des rois atlantes. Entre réoralisation de l'écrit et solution de la démocratie, p. 391-419.

JitsedIJKSTRA, Justin KROESEN, Yme KUIPER (éds), Myths, Martyrs and Modernity. Studies in the History of Religions in Honour of Jan N. Bremmer, Leiden/Boston, Brill, 2010 (Numen Book Series. Studies in the History of Religions, 127).

Martin West, The Calydonian Boar, p. 3-11; André Lardinois, Lesbian Sappho Revisited, p.13-30; Richard Buxton, The Significance (or Insignificance) of Blackness in Mythological Names, p. 31-41; Sarah Iles Johnston, The Creativity of Disaster, p. 43-58; Claude Calame, Untimely Death for the Young Girl: Etiological Foundations and Initiation Practices in Classical Athens, p. 59-74; Lautaro Roig Lanzillotta, The So-called Envy of the Gods: Revisiting a Dogma of Ancient Greek Religion, p. 75-93; Fritz Graf, Earthquakes and the Gods: Reflections on GraecoRoman Responses to Catastrophic Events, p. 95-113; Pierre Bonnechere, Oracles and Greek Mentalities: The Mantic Confirmation of Mantic Revelations, p. 116-133; Kenneth Lapatin, Pharaian Kledomancy, p. 135-143; Christopher A. Faraone, A Socratic Leaf Charm for Headache (Charmides 155B-157C), Orphic Gold Leaves, and the Ancient Greek Tradition of Leaf Amulets, p. 146-166; Ruurd R. Nauta, Callimachus' Sacrifice to Apollo Lykios (Fragment 1.21-24), p. 167-177; Anja Klöckner, Women's Affairs? On a Group of Attic Votive Reliefs with Unusual Decoration, p. 179-191; Robert Parker, New Problems in Athenian Religion: The 'Sacred Law' from Aixone, p. 193-208; Peter van Minnen, Contracting Caterers on Keos, p. 209-217; Vinciane Pirenne-Delforge, Mnasistratos, the 'Hierophant' at Andania (IG 5.1.1390 and Syll. ${ }^{3}$ 735), p. 220-235; Einar Thomassen, Gnostics and Orphics, p. 463-473.

Tobias FISCHER-HANSEN, Birte POUlSEN (éds), From Artemis to Diana. The Goddess of Man and Beast, Copenhagen, Museum Tusculanum Press, 2009. 1 vol. $17 \times 24,5 \mathrm{~cm}, 585$ p. (Acta Hyperborea, 12). ISBN : 978-87-635-0788-2.

Marie-Louise Nosch, Approaches to Artemis in Bronze Age Greece, p. 21-39; Bodil Hjerrild, Near Eastern Equivalents to Artemis, p. 41-49; Minna Skafte Jensen, Artemis in Homer, p. 51-60; Jørgen Mejer, Artemis in Athens, p. 61-77; Jørgen Mejer, A Note on a Dedication to Artemis in 
Kalydon, p. 79-81; Inge Nielsen, The Sanctuary of Artemis Brauronia. Can Architecture and Iconography Help to Locate the Settings of the Rituals?, p. 83-116; Birte Lundgreen, Boys at Brauron, p. 117-126; Ditte Zink Kaasgaard Falb, Das Artemis Orthia-Heiligtum in Sparta im 7. Und 6. Jh.v.Chr., p. 127-152; Synnøve Des Bouvrie, Artemis Orthia - a Goddess of Nature or a Goddess of Culture?, p. 153-190; Lone Wriedt Sørensen, Artemis in Cyprus, p. 195-206; Tobias Fischer-Hansen, Artemis in Sicily and South Italy: A Picture of Diversity, p. 207-260; Marjatta Nielsen, Annette Rathje, Artumes in Etruria - the Borrowed Goddess, p. 261-301; Pia Guldager Bilde, Quantifying Black Sea Artemis: Some Methodological Reflections, p. 303-332; Luis Ballesteros-Pastor, Bears and Bees in Themiscyra: A Sanctuary for Artemis in the Land of the Amazons?, p. 333-340; Mette Moltesen, Diana and her Followers in a Late Republican Temple Pediment from Nemi. A Preliminary Note, p. 345-367; Jesper Carlsen, Sanctuaries of Artemis and the Domitii Ahenobarbi, p.369-381; Rubina Raja, The Sanctuary of Artemis in Gerasa, p. 383-400; Birte Poulsen, The Sanctuaries of the Goddess of the Hunt, p. 401-425; Niels Hannestad, The Last Diana, p. 427-451; Marjatta Nielsen, Diana Efesia Multimammia: The Metamorphoses of a Pagan Goddess from the Renaissance to the Age of Neo-Classicism, p. 455-496.

Athena IAKONIDOU (éd.), Thrace in the Graeco-Roman World. Proceedings of the 10th International Congress of Thracology (October 2005), Athens, 2007.

M. Deoudi, Bendis - kultureel geprägtes Gesicht einer thrakischen Göttin, p. 120-129; D. Dimova Ivanova, Statements about Diomedes and Lycurgus in Greek Mythology, p.140-142; I. Dontcheva, Les kernoi dans le rite funéraire thrace à l'époque romaine (selon des données des nécropoles situées sur le territoire de la Bulgarie du Nord-Est), p. 143-154; Z. Gočeva, NÉos "H Cult, Hero Worship - Promblems of Past and Identity: a Thracian Case, p. 333-338; I.D. Papaikonomou, L'eau, la jeune fille et Artémis. La présence de l'eau dans l'espace de la cité d'Abdère et de ses nécropoles, p. 445-450; M.-G. Parissaki, Tracing Cults in Aegaean Thrace. The Evidence of Personal Names, p. 451-460; R. Popova, The Cult of Sabazios in the North Black SeaVia Thrace?, p. 492-499.

11 Jesper Tae JENSEN, George HINGE, Peter SCHULTZ, Bronwen WICKKISER (éds), Aspects of ancient Greek cult: context - ritual - iconography, Aarhus: Aarhus UP, 2009 (Aarhus Studies in Mediterranean Antiquity, 8).

Jesper Tae Jensen, Geirge Hinge, Peter Schultz, Bronwen Wickkiser, Preface, p. 7-8; Jesper Tae Jensen, Introduction, p. 9-11; Lisbeth Bredholt Christensen, "Cult» in the Study of Religion and Archaeology, p. 13-27; Richard Hamilton, Basket Case: Altars, Animals and Baskets on Classical Attic Votive Reliefs, p. 29-53; Bronwen Wickkiser, Banishing Plague: Asklepios, Athens, and the Great Plague Reconsidered, p.55-65; Vanda Papaefthymiou, Der Altar des Asklepieions von Athen, p. 67-89; Michaelis Lefantzis \& Jesper Tae Jensen, The Athenian Asklepieion on the South Slope of the Akropolis: Early Development, ca 420-460 B.C., p. 91-124; Peter Schultz, Divine Images and Royal Ideology in the Philippeion at Olympia, p. 125-193; Tore Tvarno Lind, Music and Cult in Ancient Greece: Ethnomusicological Perspectives, p. 195-214; Georg Hinge, Cultic Persona and the Transmission of the Partheneios, p. 215-236.

Vassos KARAGEORGHIS, Ourania KOUKA (éds), Cyprus and the East Aegean. Intercultural Contacts from 3000 to 500 BC. An International Archaeological Symposium held at Pythagoreion, Samos, October 2008, Nicosia, Leventis Foundation, 2009.

H. Kyrieleis, Intercultural commerce and diplomacy: Near Eastern, Egyptian and Cypriot artefacts from the Heraion of Samos, p.139-143; R. senff, Beasts, heroes and worshippers: Cypriot limestone statuettes from the sanctuary of Aphrodite at Miletus, p. 218-228; N. Tuna, N. Atıc1, Ü. 
Muşkara, I. Sakarya, Some remarks on the limestone figurines recently found at the Archaic sanctuary of Apollo in the territory of Knidos, p. 229-243; U. Höckmann, Male figures bearing sacrificial animals from Cyprus, the Aegean and Naukratis, p. 252-262.

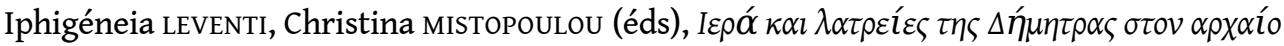

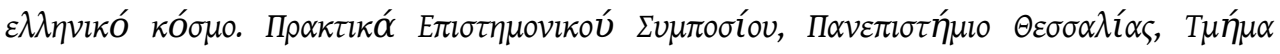

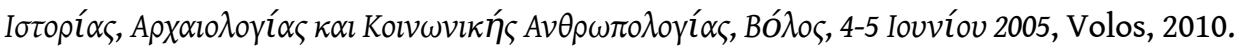

Kevin Clinton, The Eleusinian Aparche in Practice: 329/8 B.C., p. 1-15; Michalis Tibérios,

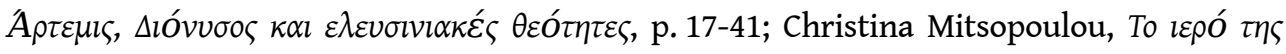

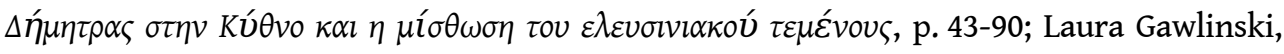

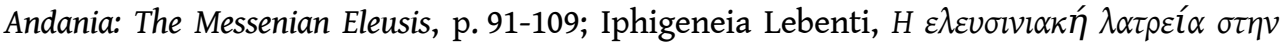

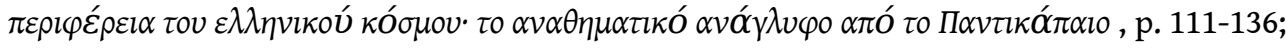
Nancy Bookidis, The Sanctuary of Demeter and Kore at Corinth: A Review and an Update,

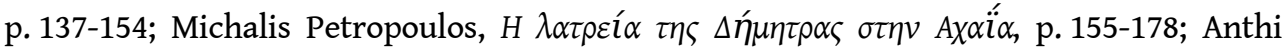

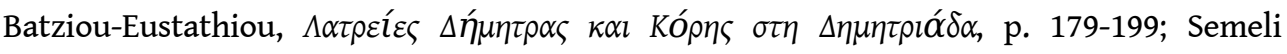

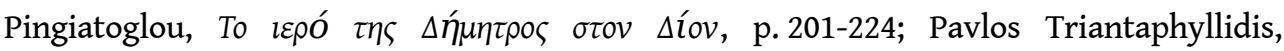

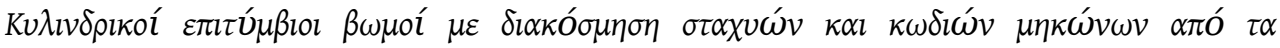

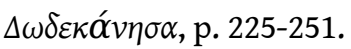

14 Joannis mylonopoulos (éd.), Divine Images and Human Imaginations in Ancient Greece and Rome, Leiden/Boston, 2010 (Religions in the Graeco-Roman World, 170).

Joannis Mylonopoulos, Divine images versus cult images. An endless story about theories, methods, and terminologies, p. 1-19; Fritz Blakolmer, A pantheon without attributes? Goddesses and gods in Minoan and Mycenean iconography, p. 21-61; Milette Gaifman, Aniconism and the notion of "primitive" in Greek antiquity, p. 63-86; Catherine M. Keesling, Finding the gods.Greek and Cypriot votive korai revisited, p. 87-103; Fernande Hölscher, Gods and Statues - An approach to archaistic images in the fifth century BCE, p. 105-120; Vinciane Pirenne-Delforge, Greek priests and "cult statues": In how far are they unnecessary?, p. 121-141; Gunnel Ekroth, Theseus and the stone. The iconographic and ritual contexts of a Greek votive relief in the Louvre, p. 143-169; Joannis Mylonopoulos, Odysseus with a trident?The use of attributes in ancient Greek imagery, p.171-203; Ivana Petrovic, The life story of a cult statue as an allegory: Kallimachos' Hermes Perpheraios, p. 205-224; Tanja Scheer, Arcadian cult images between religion and politics, p. 225-239; Dirk Steuernagel, Synnaos theos. Images of Roman emperors in Greek temples, p. 241-255; Sylvia Estienne, Simulacra deorum versus ornamenta aedium. The status of divine images in the temples of Rome, p. 257-271;Katja Moede, The dedication of cult statues at the altar. A Roman pictorial formula for the introduction of new cults, p. 273-287; Alessandra Bravi, Ornamenta, monumenta, exempla. Greek images of gods in the public spaces of Constantinople, p. 289-301.

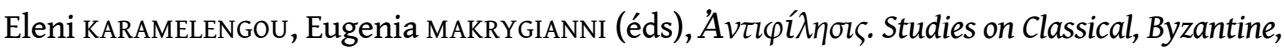
and Modern Greek Literature and Culture. In Honour of Johns-Theophanes A. Papademetriou, Stuttgart, Steiner, 2009 (Klassische Philologie).

J. Strauss Clay, How to be a Hero: The Case of Sarpedon, p. 30-38; S. Rangos, The Story of a Simile. Hidden Evidence for Dionysus in Homer and Beyond, p. 67-82; W.F. Wyatt, Hesiod's Ages, p. 92-98.

16 Catalin PARTENIE (éd.), Plato's Myths, Cambridge, Cambridge UP, 2009.

C. Partenie, Introduction, p. 1-27; M. Inwood, Plato's eschatological myths, p. 28-50; D. Sedley, Myth, punishment, and politics in the Gorgias, p. 51-76; G. Betegh, Tale, theology and teleology in 
the Phaedo, p. 77-100; M. Schofield, Fraternité, inégalité, la parole de Dieu: Plato's authoritarian myth of political legitimation, p. 101-115; G.R.F. Ferrari, Glaucon's reward, philosophy's debt: the myth of Er, p. 116-133; Ch. Rowe, The charioteer and his horses: an example of Platonic mythmaking, p. 134-147; C.H. Kahn, The myth of the Statesman, p. 148-166; M.F. Burnyeat, Eikôs muthos, p. 167-186; R. Stalley, Myth and eschatology in the Laws, p. 187-205; E. McGrath, Platonic myth in Renaissance iconography, p. 206-238.

Anders Holm RASMUSSEN, Susanne William RASMUSSEN (éds), Religion and Society. Rituals, Resources and Identity in the Ancient Graeco-Roman World. The BOMOS-Conferences 2002-2005, Roma, Edizioni Quasar, 2008 (Analecta Romana Instituti Danici, suppl. 40).

Jørgen Podemann Sørensen, A Theory of Ritual, p. 13-22; Anders Holm Rasmussen, Priest and Ritual in Ancient Greek Cult, p. 71-80; Louise Bruit Zaidman, Rites et mythes en Grèce ancienne. Sur les traces de Pausanias, p. 81-89; Veit Rosenberger, Gifts and Oracles: Aspects of Religious Communication, p. 91-106; Karen Rørby Kristensen, The "Ritual of Legislation: Some Preliminary Reflections on the Interaction of Law and Religion in Ancient Crete, p. 107-115; Björn Forsén, Resources and Manpower Needed for Constructing Greek Temples - Reflections Stemming from an Arcadian Sanctuary, p. 119-124; Kostas Buraselis, Priesthoods for Sale. Comments on Ideological and Financial Aspects of the Sale of Priesthoods in the Greek Cities of the Hellenistic and Roman Periods, p. 125-131; Anders Holm Rasmussen, Priests and Liturgies, p. 133-137; Jenny Wallensten, Resources for Manpower. Magistrates' Dedications to Aphrodite, p. 139-150; Simon Price, Memory and Ancient Greece, p. 167-178; Louise Bruit Zaidman, La notion d'archaïsme et la construction de l'identité religieuse dans le monde grec ancien, p.179-188; Jens A. Krasilnikoff, Pan, Attica and Religious Innovation from the Persian Wars to the end of the Fourth Century BC, p. 189-200; Robert Parker, $\pi \alpha \tau \rho \omega \tilde{\omega} o l ~ \theta \varepsilon o i ́:$ The Cults of Sub-Groups and Identity in the Greek World, p. 201-214; Kostas Buraselis, Woven into the Peplos. Aspects of the Combination of Ruler Cult with Elements of the Traditional Polis Identity in the Hellenistic World, p. 215-223; Veit Rosenberger, Panhellenic, Athenian, and Local Identities in the Marmor Parium?, p. 225-233; James Whitley, Identity and Sacred Topography: The Sanctuaries of Praisos in Eastern Crete, p. 235-248; Björn Forsén, Sacred Topography and Identity in Arcadia, p. 249-258.

Ann-Louise SCHALLIN (éd.), en collaboration avec Petra PAKKANEN, Encounters with Mycenaean Figures and Figurines. Papers presented at a Seminar at the Swedish Institute at Athens, 27-29 April 2001, Stockholm, Svenska Institutet i Athen, 2009. 1 vol. 16,5 × $24 \mathrm{~cm}, 195$ p. (Acta Instituti Atheniensis Regni Sueciae, Series in $\left.8^{\circ}, 20\right)$. ISBN : 978-91-7916-057-9.

Gabriele Albers, Figures and Figurines in Mycenaean Sanctuaries: Find Distributions and Contexts, p. 85-99; Helène Whittaker, The Cultic Function of Mycenaean Anthropomorphic Terracotta Figures, p.99-111; Korinna Pilafidis-Williams, The Mycenaean Kourotrophos Figurine at the Sanctuary of Aphaia on Aigina, p. 113-124; Martin Guggisberg, Animal Figures and Sacrificial Rituals at the End of the Bronze Age, p. 125-138; Leslie Hammond, Figurines, Cultic Space and the Miniature Vase, p.139-147; Petra Pakkanen, Figurines as Agents in Mycenaean Religious Ritual. An Approach from the Perspective of Religious Studies, p. 149-159; Ioulia Tzonou-Herbst, Trashing the Sacred: the Use-life of Mycenaean Figurines, p. 161-175.

Giulia SFAMENIGASPARRo, Misteri e Teologie. Per la storia dei culti mistici e misterici nel mondo antico, Cosenza, Edizioni Lionello Giordano, 2009 (HIERÁ. Collana di studi storico-religiosi, 5).

Dai misteri alla mistica: semantica di una parola, p. 49-98; Ancora sul termine TEAETH. Osservazioni storico-religiose, p. 99-117; Il mitraismo nell'ambito della fenomenologia misterica, p. 119-160; Il mitraismo: una struttura religiosa fra "tradizione" e "invenzione", p. 161-197; Riflessioni ulteriori su Mithra "dio mistico", p.199-210; Il sangue nei misteri di Mithra, 
p. 211-232; I Misteri di Mithra: religione o culto?, p. 233-247; Interpretazioni gnostiche e misteriosofiche del mito di Attis, p. 249-290; Significato e ruolo del sangue nel culto di Cibele e Attis, p. 291-327; Connotazioni metroache di Demetra nel coro dell' "Elena" (vv. 1301-1365), p. 329-372.

Amy C. SMITH, Sadie PICKUP (éds), Brill's Companion to Aphrodite, Leiden/Boston, Brill, 2010.

Vinciane Pirenne-Delforge, Flourishing Aphrodite: An Overview, p. 3-16; Sadie Pickup, Amy C. Smith, Budding Aphrodite: Into the Future, p. 17-26; Vered Lev Kenaan, Aphrodite: The Goddess of Appearances, p. 29-49; James Burbidge, O quam te memorem, virgo? Interpreting Venus in Aeneid 1.314-417, p. 51-78; Stephanie L. Budin, Aphrodite Enoplion, p. 79-112; Gabriella Pironti, Rethinking Aphrodite as a Goddess at Work, p. 113-130; Annette Teffeteller, The Song of Ares and Aphrodite: Ašertu on Skheria, p. 133-149; Kassandra Jackson, Father-Daughter Dynamics in the Iliad: The Role of Aphrodite in Defining Zeus' Regime, p. 151-163; Anja Ulbrich, Images of Cypriot Aphrodite in her Sanctuaries during the Age of the City-Kingdoms, p. 167-193; Elisabetta Pala, Aphrodite on the Akropolis: Evidence from Attic Pottery, p. 195-216; Chryssanthi Papadopoulou, Aphrodite and the Fleet in Classical Athens, p. 217-233; Alexander Nagel, Encountering the World of Aphrodite on the Western Greek Mainland, p. 235-250; Sophie Montel, The Architectural Setting of the Knidian Aphrodite, p. 251-268; Jenny Wallensten, Interactive Aphrodite: Greek Responses to the Idea of Aphrodite as Ancestress of the Romans, p. 269-284; Rachel Kousser, Augustan Aphrodites: The Allure of Greek Art in Roman Visual Culture, p. 287-306; Margherita Carucci, Aphrodite and the Spectacle of the Amphitheatre in Roman Africa, p. 307-320; Anthousa Papagiannaki, Aphrodite in Late Antique and Medieval Byzantium, p.321-346; David Bellingham, Aphrodite Deconstructed: Botticelli's Venus and Mars in the National Gallery, London, p. 347-374; Anna Gruetzner Robins, Reflections in a Mirror: Bonnard's Aphrodite, p. 375-386.

\section{Contributions particulières}

AUFFARTH Christoph, «Götterbilder im römischen Griechenland. Vom Tempel zum Museum? ", in O. HEKSTER, S. SCHMIDT-HOFNER, chr. WITSCHEL (éds), Ritual Dynamics and Religious Change in the Roman Empire. Proceedings of the Eighth Workshop of the International Network Impact of Empire (Heidelberg, July 5-7, 2007), Leiden, Brill, 2009 (Impact of Empire, 9), p. 307-325. AVRAM Alexandru, «Épigraphie et histoire religieuse. Le culte de Léto dans les cités de la Mer Noire », in A. MARTÍNEZ FERNÁNDEZ (ed.), Estudios de Epigrafía Griega, La Laguna, 2009, p. 305-313.

CALVO-MARTínez T., "La religiosité de Socrate dans Xénophon », in M. NARCY, A. T ORDESILlAs (éds), Xénophon et Socrate. Actes du colloque d'Aix-en-Provence (6-9 novembre 2003), Paris, Vrin, 2008, p. 49-64. CHANIOTIS A., "The Dynamics of Rituals in the Roman Empire ", in O. HEKSTER, S. SCHMIDTHOFNER, chr. WITSCHEL (éds), Ritual Dynamics and Religious Change in the Roman Empire, Leiden, 2009, p. 3-29. DELIVORRIAS Angelos, «The throne of Apollo at the Amyklaion: old proposals, new perspectives ", in W.G. CAVANAGH, C. GALloU, M. GEORgIADis (éds), Sparta and Laconia from Prehistory to Pre-modern, London, 2009 (BSA Studies, 16), p. 133-135. 
GERMENIA Stefania, LEGGio Daniela, «Le dee della terra: Demetra e Kore », in P.D. SCIRPo

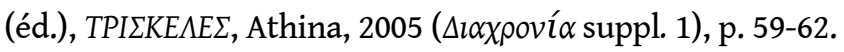

HINGE G., « Dionysos and Heracles in Scythia. The eschatological string of Herodotus' Book 4 ", in P. Guldager BiLDE, J.H. Petersen (éds), Meeting of cultures in the Black Sea Region. Between Conflict and Coexistence, Aarhus, Aarhus UP, 2008 (Black Sea Studies, 8), p. 369-397.

PARKER Robert, «A festival that moved, and other problems relating to Skirophorion », in

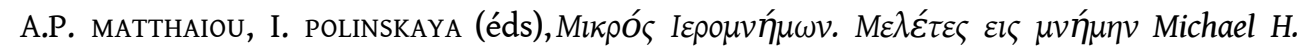
Jameson, Athènes, 2008, p. 35-39.

PARKER Robert, "Aeschylus' Gods: Drama, Cult, Theology », in Eschyle à l'aube du théâtre occidental, Vandœuvres/Genève, 2009 (Entretiens sur l'Antiquité classique, 55), p. 127-164.

PARKER Robert, « Subjection, Synoecism and Religious Life », in P. FUNKE, N. LURAGHI (éds), The Politics of Ethnicity and the Crisis of the Peloponnesian League, Cambridge, MA/London, 2009, p. 183-214.

schмiтZ W., « Menschliche und göttliche Gerechtigkeitsvorstellungen im archaischen und klassischen Griechenland", in H. BARTA, R. ROLLINGER, M. LANG (éds), Recht und Religion. Menschliche und göttlichen Gerechtigkeitsvorstellungen in den antiken Welten, Wiesbaden, Harrassowitz, 2008 (Philippika, 24), p. 155-167.

2 SCIRPO Paolo Daniele, "Sui culti delle sub-colonie arcaiche di Siracusa", in P.D. SCIRPO

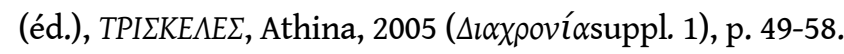

3 SVANA I., « The Rural Sanctuary at Kyra Panagia ", in B. FÓRSEN (éd.), Thesprotia Expedition I. Towards a Regional History, Helsinki, 2009 (Papers and Monographs of the Finish Institute at Athens, 15), p. 89-96.

4 WAUGH N., "Visualising fertility at Artemis Orthia's site », in W.G. CAVANAGH, C. GALLOU, M. GEORGIADIS (éds), Sparta and Laconia from Prehistory to Pre-modern, London, 2009 (BSA Studies, 16), p. 159-167. 